\title{
Improving of Educational Programs for the Formation of Information and Communication Competence of Teachers
}

\section{Mejora de los programas educativos para la formación de competencias de información y comunicación de los docentes}

\author{
Tetyana V. Grygorenko*
}

Pavlo Tychyna Uman State Pedagogical University, Uman, Ukraine

ORCID: https://orcid.org/0000-0002-4616-6853

Mykola A. Zakharevych

Pavlo Tychyna Uman State Pedagogical University, Uman, Ukraine

ORCID: https://orcid.org/0000-0003-3013-8644

\author{
Alona V. Nieliepova \\ National University of Life and Environmental Sciences of Ukraine, Kyiv, Ukraine \\ ORCID: https://orcid.org/0000-0003-2215-8311 \\ Olena S. Avdieieva \\ Berdyansk State Pedagogical University, Berdyansk, Ukraine \\ ORCID: https://orcid.org/0000-0002-1248-7819

\section{Oksana A. Holiuk} \\ Vinnytsia Mykhailo Kotsiubynskyi State Pedagogical University, Vinnytsia, Ukraine \\ ORCID: https://orcid.org/0000-0001-6309-9261
}

Received 09-08-20 Revised 10-10-20

*Correspondence

Email: grygorenko5841@unesp.co.uk
Accepted 20-12-21 On line 02-12-21

Cite as:

(c) Universidad San Ignacio de Loyola, Vicerrectorado de Investigación, 2021. 


\section{Summary}

The educational process has to manage the demand to meet all modern requirements for educational activities, which cannot be realized without proper formation of information and communication competence of teachers. The aim of this study is to identify the modern condition of formation and practice of information and communication competence of teachers in the paradigm of Ukrainian educational realities. Our task is to compare them with the practice of leading European countries and predicted directions of education-2030 with a focus on improving digital competencies of a teacher as an organizer of educational activities. A prominent place in the process of increasing the information and communication competence of teachers is occupied by the appropriate conditions for creating an information and communication environment for the formation of the future teacher of higher education institution. The methods of collection, analysis and systematization, data generalization concerning the modern condition of development of competencies in the usage of information and computer technologies by Ukrainian teachers and the whole world were used in the process of the study. An assessment of the readiness of Ukrainian teachers to provide online education has been made in the context of a world coronavirus pandemic. According to world experts, the pandemic has made radical and irreversible changes in modern ideas about learning, the role of teachers in the educational process, the set of competencies of teachers in the XXI century.

Keywords: internal system, higher education, philology, digital technologies, professional education.

\section{Resumen}

El proceso educativo tiene que gestionar la demanda para cumplir con todos los requisitos modernos para las actividades educativas, que no se pueden realizar sin la formación adecuada de la competencia de información y comunicación de los profesores. El objetivo de este estudio es identificar la condición moderna de formación y práctica de la competencia en información y comunicación de los profesores en el paradigma de las realidades educativas ucranianas. Nuestra tarea es compararlos con la práctica de los principales países europeos y las direcciones previstas de la educación2030 con un enfoque en la mejora de las competencias digitales de un docente como organizador de actividades educativas. Un lugar destacado en el proceso de aumento de la competencia en información y comunicación de los docentes lo ocupan las condiciones adecuadas para crear un ambiente de información y comunicación para la formación del futuro docente de la institución de educación superior. En el proceso del estudio se utilizaron los métodos de recopilación, análisis y sistematización, generalización de datos sobre la condición moderna de desarrollo de competencias en el uso de tecnologías de la información y la computación por parte de profesores ucranianos y del mundo entero. Según los expertos mundiales, la pandemia ha producido cambios radicales e irreversibles en las ideas modernas sobre el aprendizaje, el papel de los docentes en el proceso educativo, el conjunto de competencias de los docentes en el siglo XXI. 
Palabras clave: sistema interno, educación superior, filología, tecnologías digitales, educación profesional.

\section{Introduction}

Current trends in the development of the world community, marked by the processes of enhanced multilevel integration, have been reflected in educational processes. Education is one of the most flexible and sensitive to innovation areas of human life. Any serious intention for serious change in the world order has its origins in an educational sphere (Figure 1).

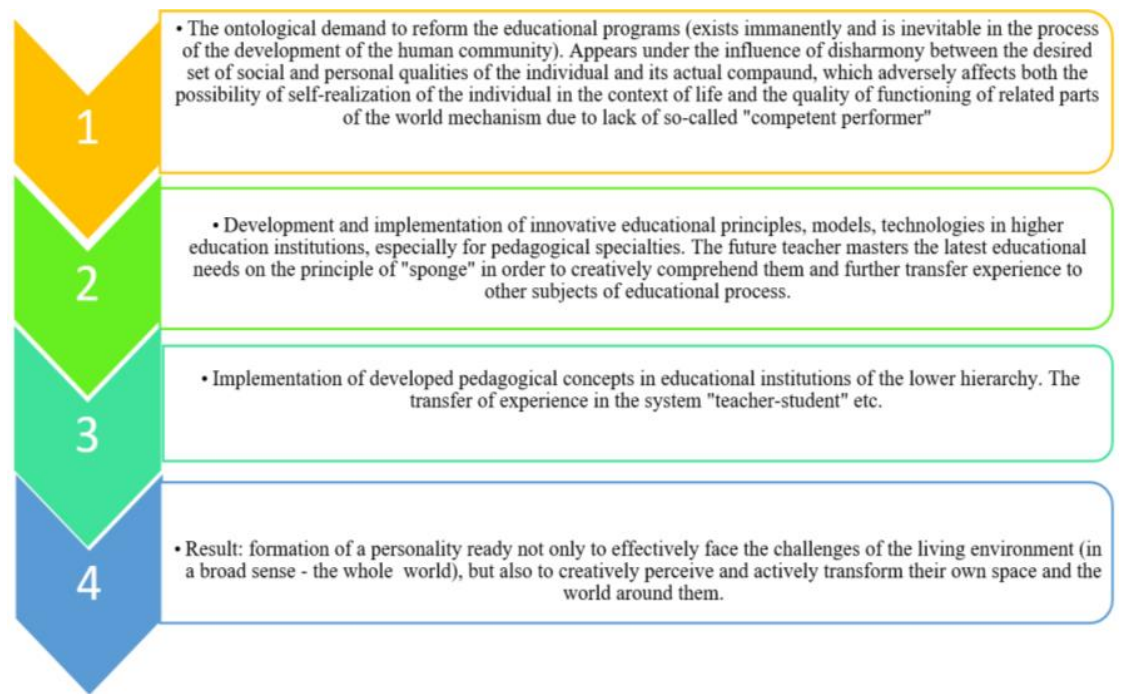

Figure 1. Higher education as a buffer between the challenges of world processes and their direct practical implementation

Source: Compiled by the author

The central role here is played by the link of higher pedagogical education. The modern principle of Business-to-Business (B2B) is formed exactly here, but in the pedagogical projection: "education for education". The seriousness of the issue of information and communication competence of future teachers has become more acute with the spread of the COVID-19 pandemic. The necessity to introduce a remote education made it possible to oversee particularly clearly the condition of readiness of Ukrainian teachers for full-fledged work in the conditions of e-learning. The key factors of success of the teams that managed to create the pedagogical process online were not only the high level of integration of all members, but also the level of skills of information and communication competence, as well as digital literacy of the participants in the pedagogical process in general. The problem of creating appropriate conditions for the formation of information and communication competence of future teachers requires the systematic improvement of educational programs. The study shows that even in the developed countries, teachers are not always satisfied with the level of development of their own digital competencies during their studies at the university (Hilbert, 2015; Khalimon et al., 2019).

A 2013 study by TALIS, a monitoring organization for teaching and learning, found that $18 \%$ of teachers in the 34 participating countries involved at the time were members of the Organization for Economic Co-operation and Development (OECD), believe that they need to develop more information and communication technology (ICT) skills for teaching, and 16\% to use new technologies in the workplace. Most of those countries were high-income ones with a high index of human development and we considered them as well-developed states (The 
OECD Teaching..., 2014). The principle of continuing professional education (provides focused learning activities, including self-education, which takes place on an ongoing basis to improve professional knowledge, skills and abilities) has been introduced into the modern world. On the other hand, information and digital technologies are evolving rapidly. Therefore, there is a growing need for regulatory and factual procedural provision of state institutions with opportunities for teachers to increase their information and communication skills at least throughout the working period (Soll, 2009; Bykova \& Ovcharuk, 2014; Redecker \& Yves, 2017; Humeniuk \& Solohub, 2020; Vorotnykova, 2020).

The aim of the scientific article is to study and generalize the domestic and European experience of improving educational programs for the formation of information and communication competence of teachers, particularly the philological department.

\section{Literature review}

In the context of formal education, which is particularly susceptible to cultural transformation processes, information and computer technologies can function as full-fledged learning tools (learning resources for teachers and students), as well as tools for interaction between learners, information storage, administrative pedagogical resources, etc. (Malik et al., 2019). The presence of ICT in higher educational institutions does not automatically guarantee their better and more efficient use. The quality of ICT usage in the learning process is determined by (Cabero \& Barroso, 2016; Areepattamannil \& Santos, 2019; Golub et al., 2019):

- the educational potential of the ICT tool (for example, too outdated model of a particular ICT device will not only be an obstacle to achieve the communicative intention of the teacher, but can also cause of a number of negative situational connotations);

- the level of formation of information and communication competence of the teacher (the ability to use appropriately available ICT to study this material in certain conditions).

The main obstacles to mastering ICT are the lack of digital literacy, in particular the lack of factual knowledge and experience of literate usage of digital technologies as data storage devices, as well as the lack of systematic support of teachers by the country to develop innovations in ICT (Kristiawan \& Muhaimin, 2019). If we are talking about the Ukrainian realities, it is worth adding the lack of technical side of the organization of the process of using ICT in the pedagogical process. The lack of digitally equipped classrooms makes it impossible to implement even the teacher's information and communication competencies, not to mention their further development, which is always associated with practice.

In the practice of ensuring the sustainable progressive development of education in Europe, significant progress has been made through the introduction of specific directives in the curricula of higher education institutions (Lozano et al., 2019). The achievements were preceded by numerous studies of practices concerning the usage of general principles of Sustainable Development (SD) and certain pedagogical approaches. A survey was developed based on the principles of integration of pedagogical approaches to sustainable development and the necessary competencies. These competencies were fixed in the educational programs of the educational institutions to study the pedagogical approaches used in European higher education institutions for the formation of pedagogical competencies. The survey was sent to a database of more than 4.000 contacts and 390 complete answers were received $(9.80 \%)$. So, the theoretical basis for better development of future teacher competencies was updated, including communicative and digital ones. Case studies, ideological and conceptual maps, social context, puzzles, life cycle analysis are favorable areas for the development of this type of competencies (Lozano et al., 2019; Malyshkin \& Halimon, 2018). 
The experience of introduction of information and communication technologies in the system of teacher education in the Scandinavian region (Denmark, Norway, Sweden and Finland) is very illustrative. These countries are world leaders in the impact of ICT on education and society and have already gained positive experience in creating their own strategies for reforming all important components of teacher education. They have used modern information and communication technologies in this process. The practice of forming information and communication competencies of future teachers shows that one of the key factors in the success of effective reform of educational programs is that progress in the usage of ICT in the system of professional training of teachers of all levels has taken place in parallel with national processes of informatization and computerization (Roliak, 2019). The results of the studies done by the experts in other countries can help more effectively implement ICT in Ukrainian pedagogical education. Here we are talking about colleagues from the European region, which have already had achievements in the formation of information and communication competencies of teachers through the reform of educational programs (Sysoieva \& Protsenko, 2020).

\section{Materials and methods}

The study actively involves the basic principles of comparative pedagogical theory and methods of teaching in higher education institutions, as well as methods of implementing the latest educational technologies in the educational process of institutions of lower levels of the educational hierarchy. Systematic, synergetic, culturological and axiological, comparative approaches to the analysis of pedagogical phenomena are used. The theoretical basis for the study were such European educational doctrines as:

- A Memorandum on Lifelong Learning (2000).

- General European Principles of Teacher Competences and Qualifications (European Commission. Common..., 2005);

- Pedagogical Constitution of Europe (2013);

- Ten European principles for improving the level of teaching and learning (European Forum for Enhanced..., 2017);

- European doctrine of digital competence of educators (Redecker \& Yves, 2017);

- The structure of ICT competence of teachers: UNESCO recommendations (2019).

The theoretical basis of the study was supplemented by such national educational policy documents as:

- Law of Ukraine No. 1556-VII "On Higher Education" (2014);

- Order of the Ministry of Education and Science of Ukraine No. 776 "On the concept of development of pedagogical education" (2018);

- Order of the Cabinet of Ministers of Ukraine No. 67-r "On the concept of development of the digital economy and society of Ukraine for 2018-2020" (2018);

- Resolution of the Cabinet of Ministers of Ukraine No. 1341 "On approval of the National Qualifications Framework" (2011);

- Law of Ukraine No. 2145-VIII “On Education (2017);

- Draft Regulations "On the distance form of general secondary education" (2020).

Today there is an approach to the formation of information and communication competence which allows the necessary transition from ICT to learning and knowledge technologies (LKT) (Gómez-Trigueros et al., 2019). The basic set of skills (Areepattamannil \& Santos, 2019; Rizal et al., 2019; Caena \& Redecker, 2019; Gottschalk, 2019), which make up the information and communication competence of the teacher, contains the categories that are described in Table 1. 
Table 1. Basic structure of information and communication competence of the teacher

\begin{tabular}{|l|l|}
\hline Information & - search and choosing the necessary educational information; \\
- getting directive information concerning the organization of the educational \\
process from the websites of public authorities; \\
- reading, downloading, printing, processing online files, evaluation of found \\
information; \\
- data storage and data transfer within the limits allowed by current \\
legislation in the field of information and copyright;
\end{tabular}

Communicative competence is understood as a system of knowledge, skills, abilities, motivation, attitude and qualities, which is a key to the overall competence of teachers and becomes one of the most fundamental components of educational pedagogical programs (Rider \& Keefer, 2006) and means the ability to effectively organize pragmatic features of communication among the participants of communication. Moreover, information competence means a set of skills that allow an individual to identify the need for information, use information effectively and make informative, intelligent, ethically sound decisions in academic, professional and private life (Zemliansky \& St. Amant, 2008). The digital competence of the teacher is understood as the ability and skill to use information technology logically, gradually and systematically in the educational process through the acquisition of principles and practical mastery of digital literacy skills (Tymchenko, 2019; Guillén-Gámez et al., 2020; Falloon, 2020). The currently developed European Structure of Digital Competence of Educators (DigCompEdu) illustrates how the defined framework of this concept can help not only to establish official goals or standards for the development of digital competence of teachers, but also to involve teachers in a reflective process of understanding their professional qualifications and development goals (Ghomi \& Redecker, 2019; Ferrari, 2013; Lozano et al., 2019; Kostruba, 2019).

\section{Results and discussion}

The latest content of pedagogical education is formed by the answers to the questions posed by such world processes as globalization and the information revolution. Chapter 6 of the Pedagogical Constitution of Europe (2013) states that the main task of teaching a European teacher is to develop the ability to practice learning as a dynamic combination of ethical values and cognitive, metacognitive, interpersonal and practical abilities and skills, knowledge and understanding. Communicative competence is among the main competencies that a 21 st century teacher should acquire in the first place (in particular, a modern teacher should be fluent in 
several European languages), and research and analytical competence are in the fifth place. The formation and development of these competencies, on the one hand, today cannot be implemented without the basics of digital literacy, and on the other hand, form a complementary tandem with the norms of digital literacy. The effectiveness of the teacher's activity directly depends on mastering the mechanisms and methods of giving educational content to students, which is outlined within the concept of learning technology (Pedagogical Constitution of Europe, 2013). Pedagogical technologies implemented through individual research of teachers using modern information tools are defined as "high pedagogical technologies". So, the concept of a modern teacher is impossible without the involvement of ICT and the acquisition of information and communication competencies (Kostruba, 2018).

The General European Principles of Teacher Competences and Qualifications state that education and the educational environment, provided by it through the adopted educational programs and appropriately organized educational environment for professional development, should ensure accessibility, reliability of provided knowledge and effective usage of technology where it is appropriate (European Commission. Education..., 2009). The pedagogical skills of students should allow them to build an optimal, comfortable learning environment for all participants in the educational process, to manage this environment while maintaining the intellectual freedom of the teacher. The usage of ICT should make it possible to integrate digital technologies effectively into teaching and learning. According to the UNESCO Recommendation Bulletin, the structure of teachers' ICT competence is complex and multilevel (Figure 2).

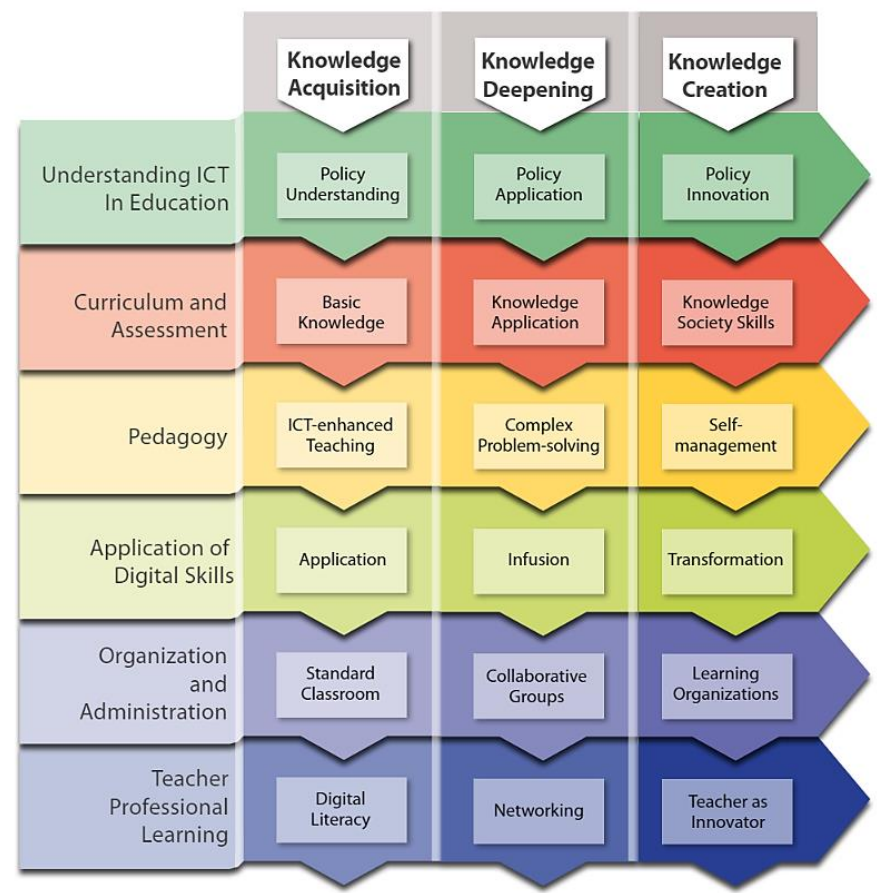

Figure 2. UNESCO ICT Competency Framework for Teachers

Source: ICT Competency Framework for Teachers (2018)

So, the structure of ICT competence is self-oriented and contains the technical and technological stages of its acquisition: self-skills. Technical side of ICT competence: I know how to solve digital problems; I can easily learn the latest educational technologies; I follow the latest important technological developments in the field of ICT in pedagogy; I often experiment with ICT technology; I know a lot of different types of ICT technologies; I have the technical skill to use ICT technology; I have enough opportunities to work with different technologies. 
Technological features of integration of pedagogical competences of ICT into the educational process on the example of teaching philological disciplines: I have technology that I can use to improve students' literacy and achieve other goals in the context of implementing state curricula; I have technology that I can use for creative and research learning of program and extracurricular material; I have the technology to assess my students' and own speaking skills; I have the technology using which I can apply a variety of language practices, develop strategies to improve own and other students' speech.

The technological side of the application of ICT competencies will always be tied to a specific area of application, the field of pedagogy. Since in this study we are interested in the information and communication environment of students of philology, we will focus on this area. Technological knowledge and skills of integration into the educational processes of ICT tools are the application of certain educational technologies, methods, techniques for effective learning. The usage of technology that meets the characteristics of the presented educational material can be a catalyst for faster learning of educational material by students. So, the accuracy of the usage of technology significantly affects the success of training (Skydan, 2009; Skydan, 2011).

The fundamental understanding of the content and vectors of development of modern pedagogical education in Ukraine is given by the Law of Ukraine No. 1556-VII "On Higher Education" (2014). Based on it, the qualification is understood as the official result of assessment and recognition, which is obtained when the authorized institution has established that the person has achieved competencies (results of the learning) in accordance with higher education standards and has a relevant document about the graduation. We can make a conclusion that competence in the structure of higher education is the result of the gaining specific knowledge and skills fixed in specific regulations. These regulations govern the set of qualities, knowledge and skills of the applicant of the educational qualification level. However, there is a strong link between the term "competence" and "results", still it does not mean that it should be taken as a fixed substance.

On the contrary, the concept of competence acquires a special dynamism and requires from the learner and from the teacher-practitioner to be aware of all innovations in ICT in order to feel confident. It is especially important when it goes about such a dynamic sphere of life of a modern person as information and communication space. It is important to be able to apply the benefits of ICT in practice and pass on the experience of ICT to students in the paradigm of modern digital achievements of all mankind. The current list of competencies of a bachelor's degree graduate in "Philology" contains integrated, general and special (professional) competencies (Standard of higher education..., 2019b). It is better to underline the following competencies. They have relation to information and communication ones: ability to learn and master modern knowledge; ability to search, process and analyze information from various sources; skills of using information and communication technologies.

The ability to use the studied language freely, flexibly and effectively, orally and in writing, in various genre and style varieties and registers of communication (formal, informal, neutral), for solving communicative tasks is indicated in the list of special (professional) skills and important in various spheres of life. The standard of higher education in the specialty "Philology" for the second (master's) level of higher education (2019a) is based on the positions specified in the bachelor's standard, but has its own features in terms of a set of qualities that form information and communication competence. For example, the ability to effectively and competently participate in various forms of scientific communication (conferences, round tables, discussions, scientific publications) in the field of philology.

The ability to participate in this form of scientific communication is just not possible without the involvement of ICT. It is necessary to generate new ideas that can be represented at 
meetings of this format. Presentation of research results is also impossible or at least suffers serious quality losses without the involvement of ICT. In addition, the format of conferences, round tables, discussions, scientific publications are increasingly moving into online space. The presence of information and communication competencies are is compulsory. The normative content of the master's degree in philology means the necessity and ability to apply properly all modern methods and informational technologies. It is necessary for the successful and effective implementation of professional activities and quality assurance of research in a particular philological field. It also states the need to follow the rules of academic integrity. Draft Law "On Education" (2015) has the definition of this concept and the set of principles that correspond to it. So, academic integrity is a set of ethical principles and rules defined by law, which should guide participants in the educational process during training, teaching and conducting scientific (creative) activities in order to ensure confidence in learning results and/or scientific (creative) achievements (Golub et al., 2020a; Golub et al., 2020b).

Keeping to academic integrity by pedagogical and scientific workers also presupposes the availability of information and communication competencies. Modern world actively involves all digital technologies in the modern understanding of the academic activity of a teacher. In particular, it contains a requirement to refer to the sources of information in case of using other people's ideas, statements, information, compliance with copyright law, providing reliable information about research results and own pedagogical (scientific, creative) activities, control over academic integrity by students. It means not only clarification the rules and principles of academic integrity, but also active involvement of relevant technologies and software in order to monitor plagiarism, etc.

As it has already been mentioned, the factor that most influenced the modern understanding of the importance of future teachers to acquire information and communication competencies and standards of digital literacy was the COVID-19 pandemic. The urgent need to organize the e-learning was put on the agenda by all levels of education institutions. The Pedagogical Constitution of Europe states that pedagogical technologies cannot be dogmatized. A teacher has the right to choose freely the technology of organization of educational activities, guided by his/her pedagogical expertise and experience of pedagogical creativity (Pedagogical Constitution of Europe, 2013). COVID-19, however, made it impossible to use any other pedagogical technologies in the educational process, except those based on remote communication of the teacher/student. The situation made it possible to work only in the digital information space with the usage of information and communication competencies.

Numerous expert opinions and predictions on the impact of the COVID-19 pandemic on the international higher education have been published in relevant media and blogs in recent months. In particular, the QS blog and the Study portals blog are noteworthy, which contain numerous articles on the COVID-19 pandemic and its impact on international higher education. In addition, organizations such as the University World News, Times Higher Education, WONKHE and the British Institute for Higher Education Policy (HEPI) blog are leading in predicting the impact of the pandemic on higher education institutions, including pedagogy sphere. DAAD, the German Academic Exchange Service, aims to provide perhaps the most comprehensive overview of the current condition of research and examination of COVID-19 in the field of international higher education (DAAD, 2020).

Mastering Internet learning resources cannot be imagined without the usage of information and communication competencies. They allow teachers and students to integrate their work when they are geographically located in different places, provide access to information and environments that are not normally available at home or in the institution (or are available but have never been used before, particularly with educational goal). Internet resources provide flexible and systematic support for the continuous and professional 
development of educators. Still, it is possible if the user has digital literacy. Distance learning requires the involvement of all types of webinars, online courses and seminars to increase the level of information and communication competencies of teachers. These types of pedagogical training have improved and become popular in recent years. But at the time of the pandemic, they were almost virtual forms of learning. They still remain in the shadow of other forms of communication that involve personal contact.

The situation with COVID-19 has led to the fact that the entire world community, including the pedagogical community, do not have questions whether online teaching is better than traditional methods of education, because this is the only form of organization of educational activities at least for some period of time (Maczuga, 2020). However, the technology and technical capabilities of distance education are not yet a total solution. Moreover, researchers of e-learning technologies during the COVID-19 pandemic note that all this is of secondary importance in the practice of distance learning (Maczuga, 2020). But the levels of formation of information and communication competence of the teacher as the organizer of educational activity come to the first one. The lack of experience and knowledge about appropriate teaching methods with the involvement of modern ICT is especially noticeable. We are talking about a nearly 100 million contingents of teachers worldwide in the formal education system alone, who are required to organize their activities remotely and actively and to use ICT on a daily basis. It necessary to make developments in the field of educational opportunities for specific field of knowledge and there is a requirement to create their own developments in the direction of implementing technologies of distance education. The situation requires immediate effective solutions. There is no time to correct systematically all gaps of pedagogical education. A base of information and communication competence should have been formed before in the university. There is no time to organize professional practice, where basic skills should develop to optimal level.

But just to wait is also not a constructive solution: we all should start learning new technologies right now. Polish researcher P. Maczuga (2020) advises to try several programs and platforms that can be tested for free: EPALE contains many training materials that are developments of the Erasmus + and Leonardo da Vinci projects, including distance learning techniques and textbooks. In addition, you should not be ashamed of failures. Experience shows that students are more likely to be willing to participate in the organization of ICT learning and can even provide useful advice on the technical side of the organization of distance learning. Such interaction will not diminish the role of the teacher or his authority in communicating with more technically educated students, but will allow the student to feel a role "teacher for teacher".

The UNESCO IESALC (2020) community has prepared a special report "COVID-19 and higher education: today and tomorrow", which examines, in particular, the problem of the activities of higher educational institutions for the period of the pandemic and the time of its finishing. Therefore, there is a need to review the modern regulatory framework in the policy of organization of higher educational institutions. First of all, it is the necessary to look at the educational process as a continuum, not a temporary phenomenon (this position resonates with the provisions of the Memorandum on Lifelong Learning (2000)). Educational directions should be planned from early childhood to higher education and in the postgraduate period. The timely and systematic use of information and communication competencies by teachers and the formation of appropriate competencies of pupils/students of all levels of the educational process will strengthen the weaknesses in the distance learning system today. The resumption of fulltime activities of higher education institutions should be seen as an opportunity and an urgent need to rethink and reformat the processes of teaching and learning with the requirement of intensive use of ICT (Reimers \& Schleicher, 2020). Governments and administrations of higher education institutions need to establish coordination mechanisms that will allow for joint 
progress in creating greater resilience in the higher education sector in the face of future crises, regardless of their nature. All this again entails the need to improve the educational programs of future teachers, without which the reform of all parts of the educational process is not realistic.

Let's speak about the rethinking of the concept of digital competence. Experts of digital media, policy development in the field of educational technologies and technology-oriented learning say that the issue of digital education, of course, is not completely new and has been discussing for about 30 years by different communities that are focused on higher education technologies (Selwyn, 2020). In particular, it is appropriate to talk about the team of Critical Digital Pedagogy and the Manifesto for Teaching Online at the University of Edinburgh. However, the issue of digital competence today should be spread and actively developed not only in relation to higher education strategies, but primarily with the projection of further integration of higher education achievements in terms of mastering digital opportunities in the educational process in school education.

According to the results of e-learning in the second half of 2019-2020 academic year in Ukraine (MES of Ukraine, 2020) mostly all teachers have mastered new online platforms during their classes, online meetings, team-works, etc. Zoom, Skype, Microsoft Teams, Google Hangouts, Google Classroom, Moodle became the most widespread platforms which were involved in educational process and with the help of which there was an active formation or gaining the skills of information and communication competences of teachers. Distance learning during quarantine revealed significant problems of distance education in Ukraine, particularly the technical barrier to conducting online learning due to the lack of access of all participants of the distance pedagogical process to modern technology and high-speed Internet. And perhaps the most relevant moment in the context of this issue in this study is that many teachers have a lack of digital skills (61\% of teachers need to improve skills in digital technologies). It indicates a lack of information and communication competence, which lasts from the time of obtaining a professional qualification in a higher education institution. So, the higher education system has its shortcomings and students do not form proper competences. It is so because of the teachers have the lack of motivation and opportunities for self-education, as well as the lack of state leverage and effective mechanism to support teachers in terms of digital literacy for postgraduate education. All this has led to the collapse of distance education during a coronavirus pandemic in Ukrainian.

Information and communication competence as a system of knowledge, skills, abilities, motivational component, etc. is an extremely important competence of a modern teacher (Zlatić et al., 2014; Guillén-Gámez et al., 2020; Falloon, 2020). Digital communication of a teacher has been one of the most important tasks of university and extracurricular training programs for European teachers for the last twenty years, (Zlatić et al., 2014; Ally, 2019). The experience of the leading countries in our world, in particular Europe, proves that information and communication competence should not remain on the periphery of the competences of future teachers or educators who already carry out practical pedagogical activities in the paradigm of formal or non-formal education, but should be formed and constantly, consciously, intentionally improve outside the walls of higher education institutions (Ferrari, 2013; Roliak, 2019; Lozano et al., 2019; Reimers \& Schleicher, 2020). The general communicative competence of the teacher increases in the process of intentional learning of digital pedagogical communication, related professional competencies are emphasized (social plasticity, unforced verbal communication, integrative style of conflict management in the learning process, managerial qualities, the ability to control the situation and self-control).

The study shows that the age and gender of the teacher also influence the prediction of the level of his/her pedagogical digital competence (Caena \& Redecker, 2019; Kristiawan \& Muhaimin, 2019). The demand to develop education in the digital age is related to the 
realization that learning during the fourth industrial revolution, modern to us, will be adaptive and individual in its nature, focused on meeting the needs of individual students. All this is possible through new digital technologies, AI and the Internet. In today's world, it is increasingly appropriate to talk not just about information and communication competence and digital literacy, but about the holistic profile of digital teacher competence (The Competency Profile for the Digital Teacher - CPDT).

New digital technologies in education will continue to transform the educational process and the role of the teacher in the individualized learning environment (Ally, 2019). The predicted development of the educational environment is so rapid that in the 2030 learning models a competent teacher will have to be able to effectively organize learning activities together with robotics teachers (Berry, 2018). All this cannot be realized without mastering the techniques and technologies of modern digital education, based on the effective and creative use of information and communication competencies of the teacher. There is a need for high-quality reformatting and rapid response to the educational demands of the era with their dynamic reflection in the provisions of the European Digital Education Area (EDEA) as a policy-making environment and mechanism for implementing digital technologies in European education systems.

Formal recognition of the directives of the European Digital Education Area is a political educational priority that should be implemented in accordance with the principles and instruments existing, for example, in the Bologna Process, for a holistic, coherent and strategic approach to digital education at EU level (Salajan, 2019). As for Ukraine, achieving at least a satisfactory level of digital education today requires significant efforts and financial investments by the state to improve the technical situation of the issue, as well as sponsorship and development of higher education, self-education and postgraduate education programs that would keep in tune and promote improving the information and communication competence of the teacher.

\section{Conclusions}

Modern challenges have forced all those involved in education to assess the social, emotional and deeply relational nature of online education, but first of all put on the agenda the issue of information and communication competence of teachers, including the problem of proper ICT skills in the acquisition paradigm in higher education. When it goes about information and communication competence, there is a need to use some of the usual procedures for interaction with digital media for a defined educational purpose, which requires doubling the efforts of the teacher by the formula "top mastery of theoretical and practical foundations of the discipline + variety of ICT + the ability to predict the result + the ability to assess the actual results of students" learning activities. The modern conditions of teaching activity of all levels of education have revealed how important it is to rethink the role of digital literacy of all participants in the educational process in the management of learning. Information and communication competence of future teachers, in particular teachers of philology, involves mastery of ICT, practical achievements in the usage of digital technologies, formed by effective learning technologies in their application.

The practice of active implementation of digital education technologies during the coronavirus pandemic in Ukraine has made a sharp necessity to restructure the educational process at all levels, starting with the training of future teachers in higher education, focusing on the competence of these teachers who can effectively organize the learning environment in the conditions of remote communication both with pupils, and colleagues and administration of educational institution. It is about the information and communication competencies of the teacher. Educational activities were at a risk without a sufficient level of formation and 
development of these competencies, as the pandemic situation significantly limited educational technologies, narrowing the potential option of teachers exclusively to those involving the Internet, web resources and digital technology. Using the Internet, both teachers and students could search and process educational information, share knowledge and form all necessary program skills. All learning results have also recorded exclusively through computerized learning tools.

\section{References}

A Memorandum on Lifelong Learning. (2000). Retrieved from: http://arhiv.acs.si/dokumenti/Memorandum_on_Lifelong_Learning.pdf.

Ally, M. (2019). Competency profile of the digital and online teacher in future education. International Review of Research in Open and Distributed Learning, 20(2), 302-318. DOI: 10.19173/irrodl.v20i2.4206.

Areepattamannil, S., Santos, I.M. (2019). Adolescent students' perceived information and communication technology (ICT) competence and autonomy: Examining links to dispositions toward science in 42 countries. Computers in Human Behavior, 98, 50-58. DOI: 10.1016/j.chb.2019.04.005.

Berry, B. (2018). The teachers of 2030: Creating a student-centered profession for the 21st century. Retrieved from: https://files.eric.ed.gov/fulltext/ED509721.pdf.

Bykova, V.Yu., Ovcharuk, O.V. (2014). Formation of information and communication competencies in the context of European integration processes of creating information educational space. Kyiv: Atika.

Cabero, J., Barroso, J. (2016). ICT teacher training: a view of the TPACK model. Culture and Education, 28(3), 633-663. DOI: 10.1080/11356405.2016.1203526.

Caena, F., Redecker, C. (2019). Aligning teacher competence frameworks to 21st century challenges: The case for the European Digital Competence Framework for Educators (Digcompedu). European Journal of Education, 54(3), 356-369. DOI: $10.1111 /$ ejed.12345.

DAAD. (2020). Retrieved from: https://www.daad.de/en/information-services-for-highereducation-institutions/centre-of-competence/covid-19-impact-on-international-highereducation-studies-and-forecasts/\#Further\%20publications.

Draft Law "On Education". (2015). Retrieved from: http://w1.c1.rada.gov.ua/pls/zweb2/webproc4_1?pf3511=57141.

Draft Regulations "On the distance form of general secondary education". (2020). Retrieved from: https://mon.gov.ua/ua/news/mon-proponuye-dlya-gromadskogo-obgovorennyaproyekt-polozhennya-pro-distancijnu-formu-zdobuttya-zagalnoyi-serednoyi-osviti.

European Commission. Common European Principles for Teacher Competencies and Qualifications. (2005). Retrieved from: http://europa.eu.int./comm/education/policies/2010/doc/principles_en.pdf.

European Commission. Education and Culture. (2009). Retrieved from: http://www.pef.unilj.si/bologna/dokumenti/eu-common-principles.pdf.

European Forum for Enhanced Collaboration in Teaching. (2017). Retrieved from: https://eua.eu/downloads/content/ten\%20european\%20principles\%20for\%20the\%20enh ancement $\% 20$ of $\% 20$ learning $\% 20$ and $\% 20$ teaching 16102017.pdf.

Falloon, G. (2020). From digital literacy to digital competence: the teacher digital competency (TDC) framework. Educational Technology Research and Development, 1-24. Retrieved from: https://link.springer.com/article/10.1007/s11423-020-09767-4.

Ferrari, A. (2013). Digcomp: A framework for developing and understanding digital competence in Europe (Report EUR 26035 EN). Seville: European Commission Joint Research Centre/Institute for Prospective Technological Studies.

Ghomi, M., Redecker, C. (2019). Digital competence of educators (DigCompEdu): Development and evaluation of a self-assessment instrument for teachers' digital 
competence. Proceedings of the 11th International Conference on Computer Supported Education (CSEDU 2019), 1, 541-548. DOI: 10.5220/0007679005410548.

Golub, G., Kukharets, S., Skydan, O., Yarosh, Y., Chuba, V., Golub, V. (2020a). The optimization of the gasifier recovery zone height when working on straw pellets. International Journal of Renewable Energy Research, 10(2), 529-536.

Golub, G., Skydan, O., Kukharets, V., Yarosh, Y., Kukharets, S. (2020b). The estimation of energetically self-sufficient agroecosystem model. Journal of Central European Agriculture, 21(1), 168-175.

Golub, G.A., Skydan, O.V., Kukharets, S.M., Marus, O.A. (2019). Substantiation of motion parameters of the substrate particles in the rotating digesters. Inmateh-Agricultural Engineering, 57(1), 179-186.

Gómez-Trigueros, I.M., Ruiz-Bañuls, M., Ortega-Sánchez, D. (2019). Digital literacy of teachers in training: Moving from ICTs (information and communication technologies) to LKTs (learning and knowledge technologies). Education Sciences, 9(4), 274.

Gottschalk, F. (2019). Impacts of technology use on children: Exploring literature on the brain, cognition and well-being. Paris: OECD Publishing.

Guillén-Gámez, F.D., Mayorga-Fernández, M.J., Bravo-Agapito, J., Escribano-Ortiz, D. (2020). Analysis of teachers' pedagogical digital competence: Identification of factors predicting their acquisition. Technology, Knowledge and Learning, 1-18. Retrieved from: https://link.springer.com/article/10.1007\%2Fs10758-019-09432-7.

Hilbert, M. (2015). Digital technology and social change. Retrieved from: https://canvas.instructure.com/courses/949415.

Humeniuk, V., Solohub, O. (2020). Andragogical concept of the development of information and communication competence of teachers in institutions of postgraduate teacher education. International Academy Journal Web of Scholar, 3(45), 42-45. DOI: $10.31435 /$ rsglobal_wos/31032020/7007.

ICT Competency Framework for Teachers. (2018). Retrieved from: https://en.unesco.org/themes/ict-education/competency-frameworkteachers\#: :text=The\%20UNESCO\%20ICT\%20Competency\%20Framework,overarchi ng\%20ICT\%20in\%20education\%20plans.

Khalimon, E., Brikoshina, I., Guseva, M., Kogotkova, I., Nikitin, S. (2019). National projects as a way to solve the problems of economic and digital disparities in different areas and regions. In: 5th IPMA SENET Project Management Conference (SENET) - Challenges of Growing Economies, pp. 105-111. Belgrade: Serbian Project Management Assoc.

Kostruba, A.V. (2018). Review of contractual obligations in the Civil Code of Ukraine. Estudios de Derecho, 76(167), 143-160.

Kostruba, A.V. (2019). Termination of contractual obligations in the civil code of Ukraine. Ius Humani-Revista de Derecho, 8, 123-142.

Kristiawan, M., Muhaimin, M. (2019). Teachers' obstacles in utilizing information and communication technology. International Journal of Educational Review, 1(2), 56-61. DOI: $10.33369 /$ ijer.v1i2.8846.

Law of Ukraine No. 1556-VII "On Higher Education". (2014). Retrieved from: http://osvita.ua/legislation/law/2235/.

Law of Ukraine No. 2145-VIII "On Education". (2017). Retrieved from: http://zakon2.rada.gov.ua/laws/show/2145-19.

Lozano, R., Barreiro-Gen, M., Lozano, F.J., Sammalisto, K. (2019). Teaching sustainability in European higher education institutions: Assessing the connections between competences and pedagogical approaches. Sustainability, 11(6), article number 1602.

Maczuga, P. (2020). Education in the Time of COVID-19. Retrieved from: https://epale.ec.europa.eu/en/blog/edukacja-w-czasach-zarazy.

Malik, S., Rohendi, D., Widiaty, I. (2019). Technological Pedagogical Content Knowledge (TPACK) with Information and Communication Technology (ICT) Integration. In book: 5th UPI International Conference on Technical and Vocational Education and 
Training (ICTVET 2018). Amsterdam: Atlantis Press. DOI: 10.2991/ictvet18.2019.114.

Malyshkin, N., Halimon, E. (2018). Analysis of level of the Russian digital economy development. Vestnik Universiteta. Retrieved from: https://vestnik.guu.ru/jour/article/view/1118

MES of Ukraine. (2020). Retrieved from: https://mon-covid19.info/uni.

Order of the Cabinet of Ministers of Ukraine No. 67-r "On the concept of development of the digital economy and society of Ukraine for 2018-2020". (2018). Retrieved from: http://zakon.rada.gov.ua/laws/show/67-2018-\%D1\%80.

Order of the Ministry of Education and Science of Ukraine No. 776 "On the concept of development of pedagogical education" (2018). Retrieved from: https://mon.gov.ua/ua/npa/pro-zatverdzhennya-koncepciyi-rozvitku-pedagogichnoyiosviti.

Pedagogical Constitution of Europe. (2013). Retrieved from: http://www.arpue.org/images/docs/Pedagogical_Constitution_of_Europe.pdf/.

Redecker, C., Yves, P. (2017). European framework for the digital competence of educators: DigCompEdu (No. JRC107466). Seville: Joint Research Centre. DOI: 10.2760/159770.

Reimers, F.M., Schleicher, A. (2020). A framework to guide an education response to the COVID-19 Pandemic of 2020. Retrieved from: https://www.hm.ee/sites/default/files/framework_guide_v1_002_harward.pdf.

Resolution of the Cabinet of Ministers of Ukraine No. 1341 "On approval of the National Qualifications Framework". (2011). Retrieved from: https://zakon.rada.gov.ua/laws/show/1341-2011-\%D0\%BF.

Rider, E., Keefer, C. (2006). Communication skills competencies: Definitions and a teaching toolbox. Medical Education, 40, 624-629. DOI: 10.1111/j.1365-2929.2006.02500.x.

Rizal, R., Rusdiana, D., Setiawan, W. (2019). Digital literacy of preservice science teacher. Journal of Physics: Conference Series, 1157(2), 022058. DOI: 10.1088/17426596/1157/2/022058.

Roliak, A.O. (2019). ICT implementation in the system of teacher education: Nordic dimension. Information Technologies and Teaching Aids, 69(1), 258-267.

Salajan, F.D. (2019). Building a policy space via mainstreaming ICT in European education: The European Digital Education Area (re) visited. European Journal of Education, 54(4), 591-604. DOI: 10.1111/ejed.12362.

Selwyn, N. (2020). Online learning: Rethinking teachers' "digital competence" in light of COVID-19. Retrieved from: https://lens.monash.edu/@education/2020/04/30/1380217/online-learning-rethinkingteachers-digital-competence-in-light-of-covid-19.

Skydan, O. (2009). The agrarian policy of rural employment regulation. Management Theory and Studies for Rural Business and Infrastructure Development, 17, 86-93.

Skydan, O. (2011). Planning for sustainable rural development. Management Theory and Studies for Rural Business and Infrastructure Development, 26, 220-226.

Soll, J. (2009). The information master: Jean-Baptiste Colbert's secret state intelligence system. Ann Arbor: University of Michigan Press.

Standard of higher education in the specialty "Philology" for the second (master's) level of higher education. (2019a). Retrieved from: https://osvita.ua/master/spec-master/65063/.

Standard of higher education in the specialty "Philology" for the first (bachelor's) level of higher education. (2019b). Retrieved from: https://osvita.ua/consultations/specbach/65055/.

Sysoieva, S., Protsenko, O. (2020). Implementation of the continuing education concept in the European educational area: Regulatory provision. Continuing Professional Education: Theory and Practice, 2, 78-84.

The OECD Teaching and Learning International Survey (TALIS) - 2013 Results. (2014). Retrieved from: http://www.oecd.org/education/school/talis-2013-results.htm. 
The structure of ICT competence of teachers: UNESCO recommendations. (2019). Retrieved from: http://pond.if.ua/attachments/article/272/rekomendacii_ikt.pdf.

Tymchenko, O.V. (2019). Formation of information and digital competence of future education specialists. Public Education: Electronic Scientific Professional Publication, 1(37). Retrieved from: https://www.narodnaosvita.kiev.ua/?page_id=5548.

UNESCO IESALC. (2020). Report "COVID-19 and higher education: Today and tomorrow. Impact analysis, policy responses and recommendations". Retrieved from: http://www.iesalc.unesco.org/en/wp-content/uploads/2020/04/COVID-19-EN-0904202.pdf.

Vorotnykova, I. (2020). Design and implementation of e-learning in postgraduate teacher education. Retrieved from: https://library.iated.org/view/VOROTNYKOVA2020DES.

Zemliansky, P., St. Amant, K. (2008). Handbook of research on virtual workplaces and the new nature of business practices. Hershey: IGI Global.

Zlatić, L., Bjekić, D., Marinković, S., Bojović, M. (2014). Development of teacher communication competence. Procedia - Social and Behavioral Sciences, 116, 606-610. DOI: 10.1016/j.sbspro.2014.01.265. 